Macmillan Business Masters

\title{
Business Accounting
}




\title{
Macmillan Business Masters
}

\author{
Business Accounting Jill Hussey and Roger Hussey \\ Company Accounts Roger Oldcorn \\ Cost and Management Accounting Jill Hussey and Roger Hussey \\ Economics S. F. Goodman \\ Financial Management Geoffrey Knott \\ Management Roger Oldcorn \\ Marketing Geoff Lancaster and Paul Reynolds \\ Marketing Research Christopher West \\ Operations Management Howard Barnett \\ Personnel Management Margaret Attwood and Stuart Dimmock
}




\section{Business}

\section{Accounting}

Jill Hussey and Roger Hussey 


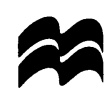

(C) Jill Hussey and Roger Hussey 1999

All rights reserved. No reproduction, copy or transmission of this publication may be made without written permission.

No paragraph of this publication may be reproduced, copied or transmitted save with written permission or in accordance with the provisions of the Copyright, Design and Patents Act 1988, or under the terms of any licence permitting limited copying issued by the Copyright Licensing Agency, 90 Tottenham Court Road, London W1P 9HE.

Any person who does any unauthorised act in relation to this publication may be liable to criminal prosecution and civil claims for damages.

The authors have asserted their rights to be identified as the authors of this work in accordance with the Copyright, Designs and Patents Act 1988.

First published 1999 by MACMILLAN PRESS LTD

Houndmills, Basingstoke, Hampshire RG21 6XS and London

Companies and representatives throughout the world

ISBN 978-0-333-73081-2

ISBN 978-1-349-14784-7 (eBook)

DOI 10.1007/978-1-349-14784-7

A catalogue record for this book is available from the British Library.

This book is printed on paper suitable for recycling and made from fully managed and sustained forest sources.

$\begin{array}{llllllllll}10 & 9 & 8 & 7 & 6 & 5 & 4 & 3 & 2 & 1\end{array}$

$\begin{array}{llllllllll}08 & 07 & 06 & 05 & 04 & 03 & 02 & 01 & 00 & 99\end{array}$

Typeset in Great Britain by

Aarontype Limited

Easton, Bristol 


\section{Contents}

Preface

\section{PART I INTRODUCTION TO ACCOUNTING}

1 The Nature of Accounting 3

1.1 Introduction 3

1.2 Definition of Accounting 3

1.3 Financial Accounting 5

1.4 Management Accounting 8

1.5 Relationship Between Financial and Management Accounting $\quad 10$

1.6 The Accounting Profession 11

1.7 Conclusions 12

Exercises $\quad 12$

2 The Users and Uses of Financial Information 15

2.1 Introduction $\quad 15$

2.2 Types of Business Organisation 15

2.3 Sources of Financial Information 19

2.4 Potential Users of Financial Information 21

2.5 Uses of Financial Information 22

2.6 Conclusions 24

Exercises 24

\section{PART II FINANCIAL ACCOUNTING}

3 The Importance of Cash 29

3.1 Introduction 29

3.2 Profit and Cash 29

3.3 Constructing a Cash Flow Forecast 31

3.4 Planning Capital Requirement 35

3.5 Planning, Control and Decision-making 36 
3.6 Using Cash Flow 38

3.7 Conclusions $\quad 39$

Exercises 39

4 The Accounting System 43

4.1 Introduction $\quad 43$

4.2 Source Documents 43

4.3 Double-entry Bookkeeping 45

4.4 Recording Assets and Liabilities 46

4.5 Recording Revenues and Expenses $\quad 50$

4.6 Recording Purchases, Sales and Stock 52

4.7 Credit Transactions $\quad 56$

4.8 Conclusions $\quad 59$

Exercises $\quad 59$

5 The Trial Balance $\quad 62$

5.1 Introduction $\quad 62$

5.2 Balancing the Accounts $\quad 62$

5.3 Constructing a Trial Balance $\quad 64$

5.4 Other Transactions $\quad 66$

5.5 Limitations of a Trial Balance $\quad 69$

$\begin{array}{lll}5.6 & \text { Conclusions } & 69\end{array}$

$\begin{array}{ll}\text { Exercises } & 70\end{array}$

6 The Profit and Loss Account of a Sole Trader 73

$\begin{array}{lll}6.1 & \text { Introduction } & 73\end{array}$

6.2 The Accruals Concept $\quad 73$

6.3 Constructing a Profit and Loss Account 74

6.4 The Profit and Loss Account and Cash Flow Statement $\begin{array}{ll}\text { Compared } & 78\end{array}$

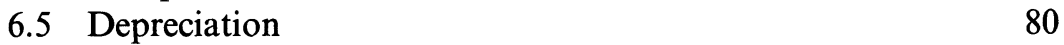

6.6 Doubtful Debts $\quad 82$

6.7 The Continuing Business $\quad 82$

$\begin{array}{ll}6.8 \text { Conclusions } & 84\end{array}$

$\begin{array}{ll}\text { Exercises } & 84\end{array}$

7 The Balance Sheet of a Sole Trader $\quad 87$

$\begin{array}{lll}7.1 & \text { Introduction } & 87\end{array}$

7.2 Purpose of the Balance Sheet 87

7.3 Constructing a Horizontal Balance Sheet 91

7.4 Constructing a Vertical Balance Sheet 93

7.5 Relationship Between the Three Financial Statements 95

$\begin{array}{ll}7.6 \text { Conclusions } & 99\end{array}$

Exercises $\quad 99$ 
8 The Final Accounts of a Sole Trader 102

$\begin{array}{lll}8.1 \text { Introduction } & 102\end{array}$

8.2 Adjustments to the Trial Balance 102

8.3 The Trial Balance with Adjustments 104

8.4 The Profit and Loss Account 104

8.5 The Balance Sheet 107

$\begin{array}{ll}8.6 \text { Conclusions } & 108\end{array}$

Exercises 109

9 The Accounts of a Partnership 113

9.1 Introduction 113

9.2 Main Features 113

9.3 The Profit and Loss Account 115

9.4 The Balance Sheet 117

9.5 Admission of a New Partner 123

9.6 Cessation of a Partnership 125

$\begin{array}{ll}9.7 \text { Conclusions } & 130\end{array}$

Exercises 131

10 Financial Reporting by Limited Companies 135

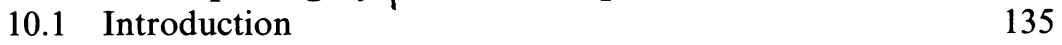

10.2 Limited Companies 135

10.3 The Regulatory Framework 137

10.4 The Annual Report and Accounts 140

10.5 International Harmonisation 141

10.6 Conclusions 142

Exercises 143

11 The Financial Statements of a Limited Company 145

11.1 Introduction 145

11.2 The Published Profit and Loss Account 145

11.3 The Published Balance Sheet 147

11.4 The Published Cash Flow Statement 149

11.5 Statement of Total Recognised Gains and Losses 150

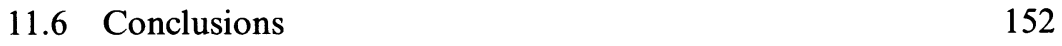

Exercises 152

12 Interpretation of Financial Statements 155

12.1 Introduction 155

12.2 Purpose of Ratios 155

12.3 Performance Ratios 157

12.4 Liquidity Ratios 160

12.5 Limitations of Ratios 163

$\begin{array}{ll}12.6 \text { Conclusions } & 164\end{array}$

Exercises 165 


\section{PART III MANAGEMENT ACCOUNTING}

13 Cost Classification

13.1 Introduction

13.2 Definition of Cost

13.3 Cost Units

13.4 Cost Centres

13.5 Cost Classification

175

13.6 Elements of Total Cost

13.7 Conclusions

Exercises

14 Cost Control Procedures

14.1 Introduction

14.2 Costing for Materials

14.3 Pricing Materials Issues

14.4 Costing for Labour

14.5 Conclusions

15.1 Introduction

15.2 Calculating Total Costs

15.3 Allocating and Apportioning Production Overheads

15.4 Overhead Cost Absorption

15.5 Calculating the Total Unit Cost

15.6 Service Cost Centres

15.7 Predetermined Overhead Absorption Rates 203

15.8 Conclusions

204

Exercises

204

16 Specific-order Costing 207

16.1 Introduction 207

16.2 Job Costing 208

16.3 Batch Costing 211

16.4 Contract Costing 213

$\begin{array}{ll}16.5 \text { Conclusions } & 219\end{array}$

Exercises 219

17 Continuous-operation Costing 223

17.1 Introduction 223

17.2 Output Costing 223

17.3 Service Costing 224

17.4 Process Costing 226 
$\begin{array}{lll}17.5 & \text { Waste } & 233\end{array}$

17.6 By-products and Joint Products 235

$\begin{array}{ll}17.7 \text { Conclusions } & 239\end{array}$

Exercises $\quad 239$

18 Marginal Costing 242

$\begin{array}{lll}18.1 \text { Introduction } & 242\end{array}$

18.2 Cost Behaviour $\quad 242$

18.3 Calculating Contribution 245

$\begin{array}{ll}18.4 & 249\end{array}$

18.5 Break-even Analysis $\quad 250$

18.6 Conclusions 253

Exercises 253

19 Capital Investment Appraisal 256

$\begin{array}{lll}19.1 & \text { Introduction } & 256\end{array}$

19.2 Purpose of Capital Investment Appraisal 256

$\begin{array}{ll}19.3 \text { Payback Period } & 257\end{array}$

19.4 Accounting Rate of Return 260

19.5 Conclusions $\quad 262$

Exercises 263

20 Discounted Cash Flow 265

20.1 Introduction $\quad 265$

20.2 Main Principles 265

20.3 Net Present Value $\quad 266$

20.4 Internal Rate of Return $\quad 267$

20.5 Information Required 270

20.6 Conclusions $\quad 271$

Exercises $\quad 271$

21 Budgetary Control $\quad 274$

$\begin{array}{lll}21.1 & \text { Introduction } & 274\end{array}$

21.2 Business Planning $\quad 274$

21.3 Purpose of Budgetary Control 277

21.4 The Budgetary Control Process $\quad 279$

$\begin{array}{lll}21.5 & \text { Variance Analysis } & 281\end{array}$

21.6 Fixed and Flexible Budgets 283

21.7 Advantages and Disadvantages 285

$\begin{array}{ll}21.8 \text { Conclusions } & 287\end{array}$

Exercises $\quad 287$

22 Standard Costing 290

22.1 Introduction $\quad 290$

22.2 Setting Standards 290

22.3 Variance Analysis $\quad 291$

22.4 Direct Materials Variances 292

22.5 Direct Labour Variances 295 
22.6 Advantages and Disadvantages

23 Developments in Management Accounting 302

23.1 Introduction

23.2 Activity-based Costing

23.3 Strategic Management Accounting

306

23.4 Throughput Accounting

23.5 Conclusions

Appendix 1: Answers to Exercises 


\section{Preface}

Accounting information lies at the heart of any business. If we are to fully appreciate the activities of companies and other business organisations, it is essential to understand their financial operations. It is therefore not surprising that accounting forms an integral part of the syllabus of many courses in universities and other institutions of higher and further education.

In recent years there has been a dramatic growth of interest in the two main subdivisions of accounting: financial accounting and management accounting. This book covers both subjects in a clear, direct style. It is suitable as a course text, supplemented by lectures, on a variety of business and management courses and other programmes of study.

Business Accounting covers the key elements of financial and management accounting and is ideal for a one-year course. The book is divided into 23 chapters which are presented in a logical teaching sequence. The text includes activities which are designed to promote understanding of the principles and the solutions add to the student's knowledge as well as providing an introduction to the next learning point. At the end of each chapter there are a variety of exercises, which are intended for selfassessment by the student, with answers at the back of the book.

JILL HUSSEY

ROGER HUSSEY 